\title{
REGULÁCIA EMÓCIÍ U DETÍ S ADHD
}

\author{
Jaroslav Lukáč, Marta Popelková \\ Katedra psychologických vied, Fakulta sociálnych vied a zdravotníctva \\ Univerzita Konštantína Filozofa v Nitre \\ jaroslav.lukac@ukf.sk,mpopelkova@ukf.sk
}

\begin{abstract}
Abstrakt: Ťažkosti s reguláciou emócií sa v súčasnosti dostávajú do pozornosti odbornej verejnosti $\mathrm{v}$ súvislosti s problémami detí, ktorým bol diagnostikovaný syndróm hyperaktivity s poruchou pozornosti. Táto prehl'adová štúdia mala za ciel' zmapovat' do akej miery sa u deti s ADHD vyskytujú t’ažkosti s reguláciou emócií a aké oblasti regulácie emócií môžu byt' pri ADHD najviac ovplyvnené. Pre tento účel sme vo viacerých databázach vyhl'adávali relevantné výskumy. Osem štúdií spíňalo kritéria pre zaradenie do prehl'adu. Z ich zistení vyplýva, že deti s ADHD majú častejšie problémy s reguláciou emócií. V záverečnej časti ponúkame odporúčania pre d’alšie výskumy.
\end{abstract}

Kl'účové slová: $A D H D$; regulácia emócií; dysregulácia emócií

\section{1 ÚVOD}

Syndróm hyperaktivity s poruchou pozornosti (ADHD-Attention-deficit/hyperactivity disorder) je vývinovou poruchou, pre ktorú sú charakteristické trvalé a vekovo neprimerané symptómy nepozornosti, hyperaktivity, alebo impulzivity, alebo ich kombinácia. Pre deti s ADHD je typické, že majú vel'ké problémy so sústredením, sú neustále v pohybe, konajú neuvážene. Diagnóza ADHD je najčastejšie diagnostikovanou detskou neurovývinovou poruchou (Danielson et al., 2018; Nair et al. 2006). ADHD má výrazný vplyv na vývin osobnosti, rodinné vzt'ahy, rovesnícke vzt'ahy a akademické predpoklady detí s touto poruchou. V poslednej dobe pribúdajú dôkazy o tom, že deti s ADHD majú problémy aj v oblasti regulácie emócií (Barkley, 2015; Faraone, et al., 2019, Shaw et al., 2014).

Reguláciu emócií (ER) možno chápat’ ako schopnost' jedinca modulovat':

(1) rýchlost' a rozsah toho, ako emócia eskaluje na fyziologickej, zážitkovej a behaviorálnej úrovni

(2) intenzitu fyziologického, zážitkového a behaviorálneho vyjadrenia emócie

(3) rýchlost' a rozsah toho, ako vyjadrenie emócie deeskaluje na fyziologickej, zážitkovej a behaviorálnej úrovni spôsobom, ktorý je kongruentný s optimálnou úrovňou fungovania jedinca (Bunford, Evans, Wymbs, 2015). Podl'a Thompsona (1994) pozostáva regulácia emócií z procesov zodpovedných za monitorovanie, vyhodnocovanie a modifikáciu emočných reakcií, najmä z pohl'adu ich intenzity a premenlivosti v čase. Tieto jednotlivé aspekty potláčajú (alebo posilňujú) intenzitu prežívanej emócie, spomal'ujú (alebo urýchl'ujú) jej nástup alebo odoznievanie, skracujú (alebo predlžujú) jej trvanie v čase, redukujú (alebo zvyšujú) jej rozsah alebo labilitu a ovplyvňujú d'alšie kvalitatívne vlastnosti emočnej odpovede (Thompson, 1994).

Reguláciu emócií možno hodnotit' tiež s ohl'adom na to, či prispieva alebo škodí adaptácii jedinca na jeho okolie (Cicchetti et al., 1991; Halligan et al., 2013). Prikláňame sa k definícii regulácie emócií podl'a Coleovej, Michelovej a Tetiovej (1994), ktoré ju chápu ako schopnost' odpovedat' na pretrvávajúce nároky životných zážitkov pomocou rôznorodej škály emócií takým spôsobom, ktorý je spoločensky tolerovatel'ný a dostatočne flexibilný, aby umožnil prežívat' spontánne reakcie a tiež schopnost' oddialit' spontánne reakcie, ak je to potrebné. 
V zahraničnej literatúre sa okrem konceptu regulácie emócií často vyskytuje aj pojem dysregulácia emócií (ED). Pre deti s ADHD je príznačná emočná impulzivita a t’ažkosti s reguláciou emócií (Faraone et al., 2019; Graziano, Garcia, 2016). Aj z toho dôvodu sa koncept dysregulácie emócií začína čoraz viac spomínat' v kontexte problémov, s ktorými sa musia sa stretávajú deti a dospelí s ADHD (Barkley, 2015). Shaw et al. (2014) vo svojej metaanalýze doterajších výskumov uvádzajú prevalenciu dysregulácie emócií u detí a mladistvých s ADHD na úrovni $24 \%-50 \%$ klinickej populácie, a až 34\% -70\% u dospelej klinickej populácie. Viacerí autori preto navrhujú zaradit’ emočnú impulzivitu a dysreguláciu emócií medzi diagnostické kritériá ADHD (Barkley, 2015; Faraone et al., 2019; Shaw et al. 2014). Prejavy dysregulácie emócií v období detstva sú považované za diagnostické kritérium ADHD v dospelosti napríklad prostredníctvom škály WURS.

Dysreguláciu emócií definuje Dodge (1991) ako narušenie schopnosti spracovávat' informácie a udalosti. Van Stralen (2016) definuje dysreguláciu emócií ako neschopnost' modulovat' emočné odozvy. Podl'a Bunfordovej et al. (2015) možno dysreguláciu emócií chápat' ako neschopnost' jednotlivca modulovat' rýchlost' a rozsah emočnej eskalácie a deeskalácie, a tiež intenzitu jej prejavov na fyziologickej, zážitkovej a behaviorálnej úrovni. Dysregulácia emócií zahŕňa podl’a Shawa et al. (2014) kontextuálne nevhodné emočné prejavy, emočnú labilitu a problémy s ciel'avedomým smerovaním pozornosti.

\section{METÓDY}

Pre potreby prehl'adovej štúdie sme uskutočnili vyhl'adávanie v databázach PubMed a Google Scholar s využitím fráz „emotion regulation in children with ADHD“ a „emotion dysregulation in children with ADHD“. Z výsledkov sme následne vylúčili štúdie v inom ako anglickom jazyku, metaanalýzy, prehl'adové štúdie, komentáre. Štúdie, ktoré sme sa rozhodli spracovat' v tejto prehl'adovej štúdii, museli spíňat' viaceré kritériá - výskumy publikované v období rokov 20002021 v databázach dostupných autorom tohto prehl’adu, využitie kvantitatívnych metód spracovania dát, využitie dotazníkových alebo pozorovacích metód zberu údajov, štatistická analýza zameraná na vzt'ah ADHD a ER/ED. Pre potreby tejto prehl'adovej štúdie sme identifikovali osem relevantných štúdií. Tie sme následne analyzovali z hl'adiska výskumného ciel'a, výskumného dizajnu, výskumných nástrojov a kl'účových zistení.

\section{VÝSLEDKY}

Prehl'ad najdôležitejších zistení pochádzajúcich zo štúdií ktoré sme zaradili do tohto prehl'adu poskytujeme v Tabul'ke 1.

Tabul'ka 1 - štúdie zaradené do prehl'adu (zoradené vzostupne podl’a roku publikovania)

\begin{tabular}{|c|c|c|c|l|}
\hline Autori & Krajina & Vzorka & Nástroje & \multicolumn{1}{|c|}{ Kl'účové zistenia } \\
\hline $\begin{array}{c}\text { Walcott, } \\
\text { Landau; }\end{array}$ & USA & $\begin{array}{c}49 \text { chlapcov } \\
\text { (26 s ADHD, 23 } \\
\text { bez ADHD) vo } \\
\text { veku 6-11 } \\
\text { rokov }\end{array}$ & $\begin{array}{c}\text { pozorovanie } \\
\text { počas riešenia } \\
\text { frustračnej úlohy }\end{array}$ & $\begin{array}{l}\text { U chlapcov s ADHD bola } \\
\text { pozorovaná vyššia miera } \\
\text { emočnej dysregulácie pri } \\
\text { riešení hlavolamu }\end{array}$ \\
\hline $\begin{array}{c}\text { Seymour et } \\
\text { al., 2012 }\end{array}$ & USA & $\begin{array}{c}69 \text { detí (37 } \\
\text { ADHD, 32 bez } \\
\text { ADHD) vo veku } \\
10-14 \text { rokov }\end{array}$ & $\begin{array}{c}\text { hodnotenie } \\
\text { rodičom (ERC), } \\
\text { sebaposudzovaci } \\
\text { a škála (DERS) }\end{array}$ & $\begin{array}{l}\text { Silná a štatisticky významná } \\
\text { korelácia medzi ADHD } \\
\text { a t'ažkost'ami s emočnou } \\
\text { reguláciou }\end{array}$ \\
\hline
\end{tabular}




\begin{tabular}{|c|c|c|c|c|}
\hline $\begin{array}{c}\text { Lugo- } \\
\text { Candelas et } \\
\text { al., } 2017\end{array}$ & USA & $\begin{array}{c}63 \text { detí ( } 29 \\
\text { s ADHD, } 34 \text { bez } \\
\text { ADHD) vo veku } \\
4-7 \text { rokov }\end{array}$ & $\begin{array}{l}\text { hodnotenie } \\
\text { matkou (ERC) }\end{array}$ & $\begin{array}{l}\text { Vyššia miera } \\
\text { negativiry/lability u detí } \\
\text { s ADHD v porovnaní } \\
\text { s kontrolnou vzorkou } \\
\text { Nižšia miera emočnej } \\
\text { regulácie u detí s ADHD } \\
\text { v porovnaní s kontrolnou } \\
\text { skupinou }\end{array}$ \\
\hline $\begin{array}{l}\text { McQuade, } \\
\text { Breaux, } \\
2017\end{array}$ & USA & $\begin{array}{l}61 \text { detí vo veku } \\
9-13 \text { rokov }\end{array}$ & $\begin{array}{c}\text { hodnotenie } \\
\text { rodičom (ERC) }\end{array}$ & $\begin{array}{l}\text { Silná a štatisticky významná } \\
\text { korelácia medzi ADHD } \\
\text { a mierou negativity/lability } \\
\text { diet'at'a } \\
\text { Stredne silná a štatisticky } \\
\text { významná negatívna korelácia } \\
\text { medzi ADHD a mierou } \\
\text { emočnej regulácie u diet’at’a }\end{array}$ \\
\hline $\begin{array}{l}\text { Fogleman et } \\
\text { al., } 2018\end{array}$ & USA & $\begin{array}{c}83 \text { detí ( } 45 \\
\text { s ADHD, } 38 \text { bez } \\
\text { ADHD) vo veku } \\
\text { 8-12 rokov }\end{array}$ & $\begin{array}{l}\text { pozorovanie } \\
\text { počas frustračnej } \\
\text { naratívnej úlohy }\end{array}$ & $\begin{array}{l}\text { Deti s ADHD preukazovali } \\
\text { vyššiu mieru problémov } \\
\text { s reguláciou negatívnych } \\
\text { emócií v porovnaní } \\
\text { s kontrolnou skupinou }\end{array}$ \\
\hline $\begin{array}{l}\text { Rosen et al., } \\
2018\end{array}$ & USA & $\begin{array}{l}52 \text { detí s ADHD } \\
\text { vo veku 9-11 } \\
\text { rokov }\end{array}$ & $\begin{array}{c}\text { hodnotenie } \\
\text { rodičom (ERC) }\end{array}$ & $\begin{array}{l}\text { Zlepšenie schopnosti regulácie } \\
\text { emócií po intervencii }\end{array}$ \\
\hline $\begin{array}{c}\text { Ozbaran, } \\
\text { Kalyoncu, } \\
\text { Kose, } 2018\end{array}$ & Turecko & $\begin{array}{l}200 \text { detí }(100 \\
\text { s ADHD, } 100 \\
\text { bez ADHD) vo } \\
\text { veku } 11-17 \\
\text { rokov }\end{array}$ & $\begin{array}{l}\text { sebaposudzovaci } \\
\text { a škála (DERS) }\end{array}$ & $\begin{array}{l}\text { Vyššia miera emočnej } \\
\text { dysregulácie u detí s ADHD } \\
\text { v porovnaní s kontrolnou } \\
\text { skupinou } \\
\text { Nižšia miera emočnej jasnosti, } \\
\text { využívania efektívnych } \\
\text { stratégií emočnej regulácie, } \\
\text { kontroly impulzov. } \\
\text { Silná a štatisticky významná } \\
\text { korelácia medzi závažnost'ou } \\
\text { symptómov ADHD a celkovým } \\
\text { skóre problémov s reguláciou } \\
\text { emócií }\end{array}$ \\
\hline $\begin{array}{l}\text { Fogleman et } \\
\text { al., } 2019\end{array}$ & USA & $\begin{array}{c}210 \text { detí }(133 \\
\text { s ADHD, } 72 \text { bez } \\
\text { ADHD) vo veku } \\
7-13 \text { rokov }\end{array}$ & $\begin{array}{c}\text { sebaposudzovaci } \\
\text { a } \\
\text { škála (ERICA) } \\
\text { a hodnotenie } \\
\text { rodičom (ERC) }\end{array}$ & $\begin{array}{l}\text { Silná a štatisticky významná } \\
\text { korelácia medzi ADHD } \\
\text { a mierou negativity/lability } \\
\text { z pohl'adu rodičov } \\
\text { Stredne silná a štatisticky } \\
\text { významná korelácia medzi } \\
\text { ADHD a mierou výskytu } \\
\text { dysregulácie }\end{array}$ \\
\hline
\end{tabular}




\section{DISKUSIA}

Ciel’om prehl'adovej štúdie bolo preskúmanie súčasných poznatkov ohl'adne regulácie a dysregulácie emócií u detí s ADHD. Väčšina skúmaných štúdií pochádzala z USA, okrem nich sa nám sme identifikovali iba jednu štúdiu ktorá vyhovovala kritériám pre zaradenie do prehl'adu a pochádzala z inej krajiny (Turecko).

\section{Výskumné ciele štúdií zaradených do prehl'adu}

Ciel’om viacerých štúdií zaradených do prehl'adu (Fogleman et al., 2018; Lugo-Candelas et al., 2017; Ozbaran, Kalyoncu, Kose, 2018; Walcott, Landau, 2004) bolo porovnat' rozdiely v regulácii emócií medzi det'mi s ADHD a det'mi bez ADHD. Fogleman et al. (2019) skúmali, či regulácia emócií u detí s ADHD súvisí s viktimizáciou zo strany rovesníkov. Seymour et al. (2012) sledovali či môže regulácia emócií pôsobit' ako mediátor vo vzt'ahu medzi ADHD a depresiou. McQuadová a Breauxová (2017) skúmali, či deti s výraznejšími symptómami ADHD vykazujú jedinečný vzorec dysregulácie emócií. Rosen et al. (2018) skúmali sa zamerali na sledovanie vplyvu intervencie zameranej na posilnenie schopnosti regulácie emócií u detí s ADHD.

\section{Výskumný dizajn štúdií zaradených do prehl'adu}

Väčšina zo štúdií zaradených do prehl'adu (Fogleman et al., 2018; Fogleman et al., 2019; LugoCandelas et al., 2017; McQuade, Breaux, 2017; Ozbaran, Kalyoncu, Kose, 2018; Seymour et al., 2012; Walcott, Landau, 2004) mala komparačný výskumný dizajn. Štúdia autorov Rosen et al. (2018) mala longitudinálny dizajn.

\section{Nástroje použité v štúdiách zaradených do prehl’adu}

Emotion Regulation Checklist (ERC; Shields, Cicchetti, 1997) je hodnotiaca škála slúžiaca na zmapovanie rodičovského vnímania emocionality a regulácie emócií u diet'at'a. Rodičia pomocou nej hodnotia frekvenciu výskytu určitého správania, ktoré súvisí s emočným nastavením diet’at’a a emočnou reguláciou. ERC tvorí 24 položiek hodnotiacich reakcie detí na emočné zážitky pomocou 4-bodovej Likertovej škály, kde 1 znamená skoro vôbec/nikdy a 4 znamená skoro vždy. ERC je rozdelená na dve subškály - Labilita/negativita a Emočná regulácia, pričom subškála labilita/negativita hodnotí prevažujúce emočné naladenie detí a subškála emočná regulácia hodnotí vhodnost' emočnej odozvy na situácie vyvolávajúce emócie.

Difficulties in Emotion Regulation Scale (DERS; Gratz and Roemer, 2004) je sebaposudzovacia škála určená na mapovanie t'ažkostí s emočnou reguláciou u detí a adolescentov. DERS tvorí 36 položiek skúmajúcich šest' oblastí súvisiacich s t'ažkost’ami s reguláciou emócií. Škála pozostáva zo subškál neakceptovanie negatívnych emócií, t’ažkosti s ciel'ovo-orientovaným správaním v podmienkach stresu, nedostatočné uvedomovanie si emócií, t’ažkosti s porozumením vlastným emóciám, obmedzený prístup k efektívnym stratégiám emočnej regulácie, t’ažkosti s ovládaním impulzívneho správania v strese. Položky sú skórované od 1-takmer nikdy po 5-takmer vždy. Celková miera t'ažkostí s emočnou reguláciou je vyjadrená súčtom dosiahnutých bodov za jednotlivé oblasti.

Emotion Regulation Index for Children and Adolescents (ERICA; MacDermott et al., 2010) je sebaposudzovacia škála určená na mapovanie emočnej regulácie u detí a adolescentov. Škálu ERICA tvorí 16 položiek, ktoré skúmajú mieru emočnej kontroly, emočného sebauvedomovania a situačnej odozvy. Respondenti svoje odpovede uvádzajú na 5-bodovej Likertovej škále, kde 1 znamená „rozhodne nesúhlasím“ a 5 znamená „rozhodne súhlasím“.

Fogleman et al. (2018) pre účely výskumu využili pozorovanie detí počas frustračnej naratívnej úlohy. Deti mali opísat' nedávny zážitok, počas ktorého cítili frustráciu. Ich výpovede boli 
nahrávané pomocou videokamery a následne kódované. Pri kódovaní sa hodnotitelia zameriavali na mieru prejavovanej frustrácie, intenzitu prejavovanej frustrácie, frekvenciu prejavovanej frustrácie, celkovú frustráciu a koherenciu príbehu. Tieto oblasti boli hodnotené pomocou 5bodových Likertových škál kde 1 znamenala žiadnu alebo nízku mieru výskytu a 5 znamenala vysokú mieru výskytu daného javu.

Walcottová a Landau (2004) pri skúmaní emočnej regulácie u detí s ADHD využili pozorovanie detí pri riešení frustračnej úlohy (hlavolamu). Priebeh riešenia úlohy a reakcie detí boli nahrávané pomocou videokamery a následne kódované. Hodnotitelia sa pri kódovaní zameriavali na tvárové, behaviorálne a hlasové prejavy emočnej regulácie, ktoré boli zoskupené do dvoch kategóriíemočná reakcia a emočná regulácia. Pri emočnej reakcii mali hodnotitelia možnost' hodnotit' bud' neprítomnost' emočnej reakcie (žiadne tvárové, behaviorálne ani hlasové prejavy emócií), mierne prejavy emócií alebo výrazné prejavy emócií (buchnutie po stole, plač). V rámci emočnej regulácie sa hodnotitelia zameriavali na ciel'ovo-orientovanú reguláciu, negatívnu odozvu (rozhádzanie hlavolamu, negatívne vyjadrenia ohl'adne úlohy, pokusy opustit' miestnost') a zahltenie (diet'a je chvíl'kovo imobilizované, odpája sa od úlohy a odmieta pokračovat').

Dôležitou témou pri skúmaní ER u detí je otázka spôsobu získavania relevantných dát. Väčšina štúdií zaradených do tohto prehl'adu získavala údaje prostredníctvom hodnotiachich škál od rodičov detí (Fogleman et al., 2019; Lugo-Candelas et al., 2017; McQuade, Breaux, 2017; Rosen et al., 2018; Seymour et al., 2012) prípadne na údaje získané pozorovaním (Fogleman et al., 2018; Walcott, Landau, 2004). Jediný výskum, ktorý získaval údaje prostredníctvom sebaposudzovacích škál, realizovali Ozbaran, Kalyoncu a Kose (2018) na vzorke starších detí a adolescentov. Otázku spol'ahlivosti takto získaných údajov je možné sledovat' napríklad pri porovnaní hodnotení zo strany rodiča a sebapsoudzovacích dotazníkov. V jednej z nami sledovaných štúdií sa pri hodnotení dysregulácie emócií zo strany rodiča objavovali štatisticky významné korelácie medzi ED a ADHD, tie sa však pri hodnotení prostredníctvom sebaposudzovacích dotazníkov nepreukázali (Fogleman et al., 2019).

\section{Kl'účové zistenia vyplývajúce zo štúdií zaradených do prehl’adu}

Vo dvoch z nami sledovaných výskumov bol preukázaný silný a štatisticky významný vzt'ah medzi ADHD a mierou negativity/lability diet'at'a, hodnotenou z pohl'adu rodiča (Fogleman et al., 2019; McQuade, Breaux, 2017). Fogleman et al. (2019) ako aj McQuadeová a Breauxová (2017) dospeli tiež k podobným zisteniam ohl’adne vzt'ahu medzi schopnost'ou regulácie emócií a ADHD. Preukázali, že medzi nimi existuje stredne silný, negatívny vzt'ah, ktorý je štatisticky významný. Zdá sa preto, že dimenzia negativity/lability by mohla vo vzt'ahu k ADHD zohrávat' výraznejšiu úlohu než dimenzia regulácia emócií. Toto zistenie môže čiastočne vysvetl'ovat' aj schopnost' detí s ADHD lepšie akceptovat' vlastné negatívne emócie v porovnaní s kontrolnou skupinou (Ozbaran, Kalyoncu, Kose, 2018). Ak deti s ADHD častejšie zažívajú negatívne emócie a zmeny nálad, sú na tieto emócie a nálady pripravené a nemajú takú výraznú potrebu ich menit’ alebo popierat'. Zároveň to môže ale poukazovat' aj na určitú rezignáciu voči snahe regulovat' vlastné emócie. V takom prípade poskytuje istú nádej zistenie, že schopnost' regulácie emócií u detí s ADHD je možné zlepšit' s pomocou na to určených intervencií (Rosen et al., 2018).

Pri porovnávaní schopnosti regulácie emócií u detí s ADHD s kontrolnou skupinou bola pozorovaná vyššia miera problémov s reguláciou emócií u detí s ADHD (Lugo-Candelas et al., 2017; Ozbaran, Kalyoncu, Kose, 2018; Walcott, Landau, 2004) a tiež vyššia miera problémov s reguláciou negatívnych emócií (Fogleman et al., 2018). U detí s ADHD bola pozorovaná tiež vyššia miera negativity/lability (Lugo-Candelas et al., 2017), ako aj nižšia miera emočnej jasnosti, využívania efektívnych stratégií emočnej regulácie, kontroly impulzov (Ozbaran, Kalyoncu, Kose, 2018). 
V dimenzii uvedomovania si vlastných emócií neboli preukázané štatisticky významné rozdiely medzi det'mi s ADHD a kontrolnou skupinou (Ozbaran, Kalyoncu, Kose, 2018).

Samotná diagnóza ADHD ešte nemusí byt' predzvest’ou problémov s reguláciou emócií. Zdá sa, že miera, do akej sa deti s týmito problémami budú stretávat', závisí aj od závažnosti symptómov ADHD. Ozbaran, Kalyoncu a Kose (2018) preukázali, že existuje silná a štatisticky významná korelácia medzi závažnost’ou symptómov ADHD a celkovým skóre problémov s reguláciou emócií. V tomto prípade môže det'om s ADHD pomôct' dodržiavanie liečby s pomocou psychofarmák, ked'že tie môžu ovplyvnit' mieru ED u detí s ADHD (Seymour et al., 2012).

\section{LIMITY A ODPORÚČANIA}

Medzi najvýraznejšie limity prehl'adovej štúdie patrili príliš malé výskumné vzorky a tiež rôznorodost' kritérií pre zaradenie participantov do výskumu (najmä čo sa týka komorbidity iných porúch), ktoré sme identifikovali vo viacerých sledovaných výskumoch. Ďalším vnímaným problémom je existencia rôznych kritérií pre diagnostikovanie ADHD v rámci jednotlivých výskumov, čo môže skresl'ovat' získané údaje. Ďalším limitom je skutočnost', že prevažná väčšina výskumov, ktoré spíňali podmienky pre zaradenie do prehl'adu pochádzala iba z USA, čo môže vplývat' na možnost' generalizácie výskumných zistení. Viaceré z výskumov zaradených do prehl'adu využívali ako zdroj údajov o regulácii emócií hodnotenia iných osôb, v tomto prípade rodičov, ktoré mohli byt' v prípade pridružených problémov v správaní skreslené. Ako d’alší nedostatok vnímame aj skutočnost', že viaceré z predkladaných štúdií neinformovali o tom, či respondenti v ich výskumoch užívali psychofarmaceutickú liečbu pre zvládanie symptómov ADHD, čo mohlo vo vel'kej miere ovplyvnit' dosiahnuté výsledky.

Realizovanie výskumov na väčších reprezentatívnych výberoch z ciel’ových populácií, jasne definované kritériá pre zaradenie resp. vyradenie z výskumného výberu, kontrola pre možný vplyv psychofarmaceutickej liečby na schopnost’ regulácie emócií, získavanie údajov o regulácii emócií z viacerých zdrojov (napr. kombinácia pozorovania, hodnotiacich a sebaposudzovacích škál) by mohli viest' k eliminovaniu nami uvedených limitov.

\section{ZÁVER}

Ciel’om prehl'adovej štúdie bolo zmapovat' súčasné poznatky o vzt’ahu medzi ADHD a reguláciou emócií. Z analyzovaných štúdií vyplýva, že u detí s ADHD je prítomná vyššia miera problémov s reguláciou emócií (Lugo-Candelas et al., 2017; Ozbaran, Kalyoncu, Kose, 2018; Walcott, Landau, 2004) a tiež vyššia miera problémov s reguláciou negatívnych emócií (Fogleman et al., 2018). U detí s ADHD bola pozorovaná tiež vyššia miera negativity/lability (Lugo-Candelas et al., 2017), ako aj nižšia miera emočnej jasnosti, využívania efektívnych stratégií emočnej regulácie, kontroly impulzov (Ozbaran, Kalyoncu, Kose, 2018). Zároveň existuje silná a štatisticky významná korelácia medzi závažnost'ou symptómov ADHD a celkovým skóre problémov s reguláciou emócií (Ozbaran, Kalyoncu, Kose, 2018). Na tieto problémy je však možné pôsobit' intervenčne a pomôct' tak zlepšit' reguláciu emócií u detí s ADHD (Rosen et al., 2018).

\section{LITERATÚRA}

Barkley, R. A. (2015). History of ADHD. In R. A. Barkley (Ed.), Attention-deficit hyperactivity disorder: A handbook for diagnosis and treatment (3rd ed.). p. 3-51. New York: Guilford Press.

Bunford, N., Evans, S. W., \& Wymbs, F. (2015). ADHD and Emotion Dysregulation Among Children and Adolescents. Clinical child and family psychology review, 18(3), 185-217. https://doi.org/10.1007/s10567-015-0187-5 
Cicchetti, D., Ganiban, J., \& Barnett, D. (1991). Contributions from the study of high-risk populations to understanding the development of emotion regulation. In J. Garber \& K. A. Dodge (Eds.), Cambridge studies in social and emotional development. The development of emotion regulation and dysregulation, 15-48. Cambridge University Press. https://doi.org/10.1017/CB09780511663963.003

Cole, P. M., Michel, M. K., \& Teti, L. O. (1994). The development of emotion regulation and dysregulation: A clinical perspective. Monographs of the Society for Research in Child Development, 59(2-3), 73-100. https://doi.org/10.2307/1166139

Danielson, M. L., Bitsko, R. H., Ghandour, R. M., Holbrook, J. R., Kogan, M. D., \& Blumberg, S. J. (2018). Prevalence of Parent-Reported ADHD Diagnosis and Associated Treatment Among U.S. Children and Adolescents. Journal of clinical child and adolescent psychology: the official journal for the Society of Clinical Child and Adolescent Psychology, American Psychological Association, Division 53, 47(2), 199-212. https://doi.org/10.1080/15374416.2017.1417860

Dodge, K. A. (1991). Emotion and social information processing. In J. Garber \& K. A. Dodge (Eds.), Cambridge studies in social and emotional development. The development of emotion regulation and dysregulation (p. 159-181). Cambridge University Press. https://doi.org/10.1017/CB09780511663963.009

Faraone, S. V., Rostain, A. L., Blader, J., Busch, B., Childress, A. C., Connor, D. F., \& Newcorn, J. H. (2019). Practitioner Review: Emotional dysregulation in attention-deficit/hyperactivity disorder implications for clinical recognition and intervention. Journal of child psychology and psychiatry, and allied disciplines, 60(2), 133-150. https://doi.org/10.1111/jcpp.12899

Fogleman, N. D., Leaberry, K. D., Rosen, P. J., Walerius, D. M., \& Slaughter, K.. (2018). How do children with and without ADHD talk about frustration?: Use of a novel emotion narrative recall task. $A D H D$ Attention Deficit and Hyperactivity Disorders, 10(4), 297-307. https://doi.org/10.1007/s12402018-0255-z

Fogleman, N. D., Slaughter, K. E., Rosen, P. J., Leaberry, K. D., \& Walerius, D. M.. (2019). Emotion regulation accounts for the relation between ADHD and peer victimization. Journal of Child and Family Studies, 28(9), 2429-2442. https://doi.org/10.1007/s10826-018-1297-8

Graziano, P. A., \& Garcia, A. (2016). Attention-deficit hyperactivity disorder and children's emotion dysregulation: A meta-analysis. Clinical psychology review, 46, 106-123. https://doi.org/10.1016/j.cpr.2016.04.011

Halligan, S. L., Cooper, P. J., Fearon, P., Wheeler, S. L., Crosby, M., \& Murray, L. (2013). The longitudinal development of emotion regulation capacities in children at risk for externalizing disorders. Development and psychopathology, 25(2), 391-406. https://doi.org/10.1017/S0954579412001137

Lugo-Candelas, C., Flegenheimer, C., Mcdermott, J. M., \& Harvey, E.. (2017). Emotional Understanding, Reactivity, and Regulation in Young Children with ADHD Symptoms. Journal of Abnormal Child Psychology, 45(7), 1297-1310. https://doi.org/10.1007/s10802-016-0244-7

Mcquade, J. D., \& Breaux, R. P.. (2017). Are Elevations in ADHD Symptoms Associated with Physiological Reactivity and Emotion Dysregulation in Children?. Journal of Abnormal Child Psychology, 45(6), 1091-1103. https://doi.org/10.1007/s10802-016-0227-8

Nair, J., Ehimare, U., Beitman, B. D., Nair, S. S., Lavin, A. (2006). Clinical review: evidence-based diagnosis and treatment of ADHD in children. Missouri medicine, 103(6), 617-621. 
Özbaran, B., Kalyoncu, T., \& Köse, S. (2018). Theory of mind and emotion regulation difficulties in

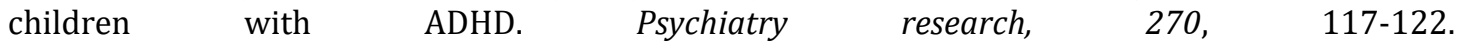
https://doi.org/10.1016/j.psychres.2018.09.034

Rosen, P. J., Leaberry, K. D., Slaughter, K., Fogleman, N. D., Walerius, D. M., Loren, R. E. A., \& Epstein, J. N. (2019). Managing Frustration for Children (MFC) Group Intervention for ADHD: An Open Trial of a Novel Group Intervention for Deficient Emotion Regulation. Cognitive and Behavioral Practice, 26(3), 522-534. https://doi.org/10.1016/j.cbpra.2018.04.002

Shaw, P., Stringaris, A., Nigg, J., \& Leibenluft, E. (2014). Emotion dysregulation in attention deficit hyperactivity disorder. The American journal of psychiatry, 171(3), 276-293. https://doi.org/10.1176/appi.ajp.2013.13070966

Seymour, K. E., Chronis-Tuscano, A., Halldorsdottir, T., Stupica, B., Owens, K., \& Sacks, T. (2012). Emotion Regulation Mediates the Relationship between ADHD and Depressive Symptoms in Youth. Journal of Abnormal Child Psychology, 40(4), 595-606. https://doi.org/10.1007/s10802-011-95934

Thompson, R. A. (1994). Emotion regulation: A theme in search of definition. Monographs of the Society for Research in Child Development, 59(2-3), 25-52. https://doi.org/10.2307/1166137

Thorell , L., Rydell, A., \& Bohlin, G. (2012) Parent-child attachment and executive functioning in relation to ADHD symptoms in middle childhood, Attachment Human Development, 14(5), 517532, DOI: $10.1080 / 14616734.2012 .706396$

van Stralen J. (2016). Emotional dysregulation in children with attention-deficit/hyperactivity disorder. Attention deficit and hyperactivity disorders, 8(4), 175-187. https://doi.org/10.1007/s12402-016-0199-0

Walcott, C. M., \& Landau, S. (2004). The relation between disinhibition and emotion regulation in boys with attention deficit hyperactivity disorder. Journal of clinical child and adolescent psychology, 33(4), 772-782. https://doi.org/10.1207/s15374424jccp3304 12

\section{EMOTION REGULATION IN CHILDREN WITH ADHD}

Abstract: Difficulties regarding emotion regulation in children diagnosed with ADHD are currently receiving considerable attention from the proffesional community. The aim of this literature review was to map the occurence of emotion regulation difficulties in children with ADHD and provide an overview of the main areas of emotion regulation difficulties faced by children with ADHD. In order to do so, we conducted a database search for relevant studies. Eight studies met the inclusion criteria for this literature review. The results of these studies show that children with ADHD face considerable emotion regulation difficulties. We discuss recommendations for future research on this topic.

Keywords: ADHD; emotion regulation; emotion dysregulation

\section{Grantová podpora:}

Článok vznikol vd’aka podpore z projektov: VEGA:1/0639/19 Kognitívne, osobnostné a sociálne charakteristiky detí s vybraným neurovývinovým ochorením; a UGA:IX/5/21 Rané maladaptívne schémy, regulácia negatívnych emócií a kvalita vzt'ahovej väzby u detí v mladšom školskom veku. 